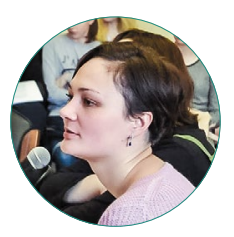

И.В. Лисовская

\title{
ПЕРЕВОСПИТАТЬ НЕЛЬЗЯ НАКАЗЫВАТЬ? КАК КОНСТРУИРУЮТСЯ СЦЕНАРИИ РЕИНТЕГРАЦИИ И РЕСОЦИАЛИЗАЦИИ “ТРУДНЫХ" ПОДРОСТКОВ
}

\section{Правильная ссылка на статью:}

Лисовская И. В. Перевоспитать нельзя наказывать? Как конструируются сценарии реинтеграции и ресоциализации "трудных" подростков // Мониторинг общественного мнения: экономические и социальные перемены. 2021. № 2. С. 383-402. https://doi.org/10.14515/ monitoring.2021.2.599.

\section{For citation:}

Lisovskaya I. V. (2021) Re-Educate, Not Punish? How Scenarios for the Reintegration and Resocialization of "Troubled" Adolescents Are Constructed. Monitoring of Public Opinion: Economic and Social Changes. No. 2. P. 383-402. https://doi.org/10.14515/monitoring. 2021.2.599. (In Russ.) 
ПЕРЕВОСПИТАТЬ НЕЛЬЗЯ НАКАЗЫВАТЬ? КАК КОНСТРУИРУЮТСЯ СЦЕНАРИИ РЕИНТЕГРАЦИИ И РЕСОЦИАЛИЗАЦИИ «ТРУДНЫХ» ПОДРОСТКОВ

ЛИСОВСКАЯ Ирина Викторовна - кандидат социологических наук, младший научный сотрудник Центра молодежных исследований, Национальный исследовательский университет "Высшая школа экономики", Санкт-Петербург, Россия

E-MAIL: ilisovskaya.hse@mail.ru

https://orcid.org/0000-0001-6495-1970

Аннотация. В статье описывается применение сценарного подхода к анализу процессов ресоциализации и реинтеграции "трудных" подростков, воспитывающихся в социальноподдерживающих организациях. В качестве исследовательской стратегии используется кейс-стади, детально изучаются четыре случая (учреждения) с использованием методов: полуструктурированного интервью с подростками $(n=29)$; экспертного интервью с работниками социально-поддерживающих организаций $(n=11)$; включенного наблюдения и анализа документов. Отвечая на исследовательский вопрос, какие существуют сценарии реинтеграции и ресоциализации "трудных" подростков, и каким образом они конструируются, автор выделяет группы образующих и частных критериев. Приводится пять сценариев: "слияния", "Выхода за рамки", "подчинения режиму", "беглеца" и "изоляции", которые отображают ситуативные модели поведения подростков, воспитывающихся в социально-поддерживающих организациях; трансформацию опыта социальной группы под воздействием институцио-
RE-EDUCATE, NOT PUNISH? HOW SCENARIOS FOR THE REINTEGRATION AND RESOCIALIZATION OF “TROUBLED” ADOLESCENTS ARE CONSTRUCTED

Irina V. LISOVSKAYA ${ }^{1}$ - Cand. Sci. (Soc.), Junior Research Fellow, Center for Youth Studies

E-MAIL: ilisovskaya.hse@mail.ru

https://orcid.org/0000-0001-6495-1970

\footnotetext{
${ }^{1}$ National Research University Higher School of Economics, Saint-Petersburg, Russia
}

Abstract. The article describes the application of scenario approach to the analysis of resocialization and reintegration of "troubled" adolescents brought up in social assistance organizations. Casestudy is used as the research strategy, four cases (institutions) are investigated in detail using the following methods: semi-structured interviews with the adolescents $(n=29)$; expert interviews with the personnel of the social assistance organizations ( $n=11)$; the participant observation and the analysis of documents. Answering the research question about what scenarios exist for reintegration and resocialization of "troubled" adolescents and how they are constructed, the author emphasizes groups of constituent and partial criteria. Five scenarios are pointed out: "convergence", "going beyond", "submission to the regime", "fugitive" and "isolation", which reflect the situational patterns of the behavior of the adolescents brought up in social assistance organizations, as well as the transformation of the experience of a social group under the influence of the institutional design of the organization, modes of relationships between the personnel and the students, various 
нального дизайна организации; режимов взаимоотношений между работниками и воспитанниками; различных частных особенностей случаев. В статье также анализируются возможности сценарного подхода - его достоинства и недостатки.

Ключевые слова: "трудные» подростки, ресоциализация, реинтеграция, социально-поддерживающие организации, восстановительное правосудие, сценарный подход, ювенальная юстиция

Благодарность. Выражаю благодарность моей научной руководительнице Омельченко Елене, внесшей огромный вклад в кандидатскую диссертацию (защищена в январе 2019 г), по материалам которой написана эта статья, обобщающая ключевые выводы. Также большая благодарность всем организациям, принявшим участие в исследовании, всем неравнодушным проводникам, информантам, согласившимся на интервью, а также моему со-интервьюеру в одном из кейсовБагуриной Ольге. special features of the cases. The article also analyzes the possibilities of scenario approach - its advantages and disadvantages.

Keywords: "troubled" adolescents, resocialization, reintegration, social assistance organizations, restorative justice, scenario approach , juvenile justice

Acknowledgments. I would like to express my gratitude to my scientific advisor prof. Elena Omelchenko, who provided me with great help and support in preparing my $\mathrm{Ph}$. D. thesis (defended in January 2019), on the basis of which this article has been written. I also express my gratitude to all the organizations that took part in my study; all caring guides; the informants who agreed to be interviewed, as well as my co-interviewer in one of the cases - Olga Bagurina.

\section{"Трудные" подростки: рисковые практики и стигматизация}

В российских медиа, государственной риторике и научном дискурсе часто можно встретить условно академический термин "трудный подросток". Как правило, он включает множество ярлыков, детализирует и характеризует отдельные действия молодежи, попадающие в разряд риска и общественной угрозы. Так, на основании степени риска Б. Павлов выделяет множество подкатегорий в определении "трудный подросток". К наиболее "рисковым" относятся "криминальный остаток", "несовершеннолетние правонарушители", а к наименее - обитатели подъездов и подворотен, беспризорные "дети-бегунки", употребляющие ненормативную лексику, молодые "алкоголики" и "курильщики" [Павлов, 2013: 70]. Такой подход характеризует исключительно поступки, неодобряемые общественностью, вызывающие "страх за молодежь" и моральные паники [Омельченко, 2004; Ярская, Ловцова, 2010].

С декриминализацией или, наоборот, криминализацией отдельных практик в законодательстве зачастую конструируются новые явления, относящиеся к ка- 
тегории риска [Surette, 2016]. Конструирование риска как феномена, несущего опасность для общества,- - это исторический процесс, трансформирующийся под влиянием общественного прогресса, изменения взглядов на общепринятые нормы [Swadener, Lubeck, 1995]. Поэтому с подобными модификациями в законодательстве, общественном мнении, доминантной культуре и веяниях мейнстрима к риску может быть приписана потенциально любая практика [Tait, 1995]. Таким образом, "трудностью" в поведении подростков становится практически все, что не соответствует нормам доминантной культуры в обществе.

Подростковый возраст напрямую связан с рисковыми практиками. Молодой человек социализируется в определенном нормативном пространстве, и стремление "выйти за рамки" попадает в разряд риска [Омельченко, 2000; Griffin, 1993]. Подросток, познавая социальную реальность, сталкивается с неподвижными социальными институтами, которые структурируют и регламентируют его повседневность, вменяют определенные стили поведения, требуют неукоснительного соблюдения норм, принятых в конкретной культуре [Омельченко, 2006]. Наряду с этим появляются “аутсайдерские» группы, не вписывающиеся в установленные рамки. Говард Бэккер использует подход деконструирования девиантности к понимаю и интерпретации образа жизни "аутсайдеров" и рассматривает их как группы со своими нормами и представлением о девиациях [Беккер, 2018].

Термин "трудный подросток", повсеместно используемый в разных дискурсах, можно рассматривать как эквивалент термина "аутсайдеры", в особенности если речь идет о группах молодых людей, воспитывающихся в специализированных организациях с целью нормативной регуляции и стандартизации их поведения для последующего “возвращения" в общество.

\section{Процессы ресоциализации и реинтеграции: в чем их отличия?}

Ряд организаций работает по принципам восстановительного подхода с целью ресоциализации "мягкими" методами - нормативной регуляции поведения и восстановления социального статуса подростка, испытывавшего эксклюзию, совершавшего правонарушения [Головизнина, 2007]. Данное понимание ресоциализации как определенного комплекса программ, направленных на восстановление социального статуса, интерпретировано с опорой на подход Энтони Гидденса, который включает в определение ресоциализации восстановление контакта индивида с обществом [Giddens, 1999]. Тем не менее в данной работе под ресоциализацией я понимаю определенную политику некоего социального института, который имеет своей целью изменение жизненного сценария подростка в контексте перевоспитания, формирование социальных ролей, не связанных с правонарушениями; восстановление социального статуса и переход от "девиантного" к "нормальному" состоянию через преодоление идентификаций с ярлыками. Ресоциализация определяется режимом и повседневностью организации, и ее воздействие на подростка оказывается субъективным. Близким по смыслу понятием является реинтеграция. В широком смысле реинтеграция - это «возвращение" индивида к нормальной жизни, восстановление связей и коммуникации с обществом. Данное явление чаще всего рассматривается на примере демобилизации военных с мест вооруженных конфликтов [Humphreys, Weinstein; 2007], 
а также возвращения бывших заключенных из тюрем [Burnett, 2009]. Термин "реинтеграция" употребляется также по отношению к мигрантам, вынужденным вернуться на родину. В этом случае реинтеграция понимается как встраивание в повседневный порядок вещей конкретного общества, член которого "Выпал" из него на неопределенный период [Бредникова, 2017; Arowolo, 2000]. В более узком смысле реинтеграция - это направление социальной политики в создании программ, помогающих индивиду в восстановлении социальных связей в результате резкого изменения социальной среды [Ward, Maruna, 2007; Burnet, Maruna, 2006]. В своей работе я использую понятие реинтеграции в узком смысле, интерпретируя его как конкретную программу или политику учреждения, направленную на встраивание подростка в городские институты, например секции, досуговые учреждения, молодежные культуры. Таким образом, под ресоциализацией понимается направление работы и программы учреждения в целом по восстановлению социального статуса подростка, преодолению им стигматизации, разрыву связей с криминальными культурами, если таковые имеются. Реинтеграция - это комплекс узких мероприятий или программ, направленных на встраивание подростка в общество.

\section{Специализированные учреждения: новизна исследования}

Каждое общество стремится провести "границы нормальности", определить норму и патологию, предложить способы и инструменты коррекции девиации. В исследовании антропологов А. Клепиковой и И. Утехина, проведенном в психоневрологическом интернате, подчеркивается, что создание специализированных учреждений «определяет, как культура понимает потребности, пределы и пути развития такого ребенка" [Клепикова, Утехин, 2010: 4]. Специализированные учреждения, в которых обучаются молодые люди, имеющие конфликты с законом, фактически считаются учреждениями для "девиантных" детей и подростков, требующих особого подхода в воспитании. Поэтому в них есть специфические программы, направленные на коррекцию поведения воспитанников посредством их ресоциализации, исходя из восстановительного подхода. Новизна моего исследования заключается в том, что я рассматриваю несколько случаев коррекции поведения подростков через их ресоциализацию и реинтеграцию в специализированных учреждениях, отличающихся друг от друга методами воспитания, но использующих восстановительный, а не изолирующий подростка от общества подход.

Учреждения, практикующие восстановительный подход, Мэри Маколи определяет как "социально-поддерживающие организации", одной из целей которых считается реинтеграция и ресоциализация подростков, совершавших правонарушения/склонных к ним, без применения принудительной изоляции [Маколи, 2008]. Я использую термин "социально-поддерживающие организации", поскольку он позволяет объединить все открытые спецшколы, училища и секции, использующие восстановительный подход в ресоциализации трудных подростков. В целом система ювенальной юстиции в России, несмотря на отсутствие прямого законодательства, имеет неоправданно сложную и разрозненную структуру, обладающую рядом проблем в реализации своих основных задач [Muravyeva, 2017; Сидоров, Бондаренко, 2012]. К социально-поддерживающим я отношу 
организации государственного сектора: специальные учебно-воспитательные учреждения отрытого типа, центры психолого-педагогической реабилитации и коррекции, школы, реализующие адаптированные программы (VII вида $\left.{ }^{1}\right)$, организации гражданского общества - специализированные некоммерческие организации дополнительного образования или предоставляющие социальнокультурные услуги [Лисовская, 2019].

\section{Сценарный подход к исследованию ресоциализации "трудных" подростков}

Нормативное перевоспитание подростков в социально-поддерживающих организациях осуществляется по разным культурным сценариям. Отличие заданных условий внешней среды, институционального дизайна (комплекса реализуемых программ), режимов взаимоотношений внутри социальных групп в конкретной организации предполагает различные модели поведения воспитанников, а также развитие событий в целом. Сценарный подход, чаще всего используемый в миграционных и гендерных исследованиях, определяет ключевые сценарии развития биографий индивидов в конкретных средовых и культурных контекстах. Ключевой сценарий интерпретируется как модель, растиражированная биография, характерная для конкретной социальной группы [Ortner, 1973; Лернер, Рапопорт, Ломски-Федер, 2009; Бредникова, 2017]. В данной статье я использую сценарный подход в контексте реинтеграции и ресоциализации молодых людей в социально-поддерживающих организациях. Под сценариями реинтеграции и ресоциализации я понимаю ситуативные модели поведения и последовательных действий "трудных" подростков в вариативных условиях обучения в различных социально-поддерживающих организациях.

Цель статьи заключается в интерпретации сценариев реинтеграции и ресоциализации "трудных" подростков и понимании критериев их конструирования на примере четырех случаев социально-поддерживающих организаций. Предпринята попытка ответить на следующие поставленные мной исследовательские вопросы: какие существуют сценарии реинтеграции и ресоциализации "трудных" подростков, каким образом они конструируются?

Эмпирическую базу исследования составляют четыре кейса социальноподдерживающих организаций, расположенных в различных городах России (городе федерального значения, областном центре, районном центре). Три из них относятся к государственным - два учебно-воспитательных учреждения открытого типа (общеобразовательная школа и профессиональное училище) и общеобразовательная школа, реализующая адаптированные программы (VII вида). Сектор гражданского общества представлен некоммерческой организацией, предоставляющей социально-культурные услуги с цирковым уклоном. Все организации используют восстановительный подход, работают с подростками, совершавшими противоправные действия, имеющими серьезные формы педаго-

\footnotetext{
1 В системе образования существует восемь основных видов коррекционных образовательных учреждений. В школах VII вида обучаются дети, имеющие задержку психического развития. Как правило, в школы такого типа могут направляться для обучения также дети и подростки, находящиеся в трудной жизненной ситуации, имеющие приводы в полицию, если в городе отсутствуют специальные профильные учреждения или в них не хватает мест.
} 
гической запущенности, пережившими травматический опыт в детстве. Молодые люди направляются в них с личного согласия и/или согласия их законных представителей. В общей сложности мною собрано 40 интервью с подростками $(n=29)$ и педагогами $(n=12)$ социально-поддерживающих организаций.

\section{Образующие критерии: роли и декорации, конструирующие типичные модели}

Особенность социально-поддерживающих организаций в России, в которых обучаются и воспитываются "трудные" подростки, заключается в отсутствии координации управления. Специальные учебно-воспитательные учреждения, к примеру, крайне немногочисленны, представлены не во всех городах и поселениях. В результате бразды нормативного перевоспитания молодежи берут на себя структуры, близкие по роду деятельности, косвенно затрагивающие работу с "трудными" подростками, например, школы VII вида и инициативные проекты гражданского общества. Некоторые организации гендерно ориентированы, другие - смешанные. Таким образом, все социально-поддерживающие учреждения различаются институциональным дизайном, уклоном деятельности или подготовки (профессиональная, творческая, общеобразовательная и т. д.), гендерными режимами и политиками, законодательным регулированием, характеристиками территориального размещения и целым набором других признаков. Специфичность деятельности каждого отдельного случая, с одной стороны, затрудняет анализ полевого материала, собранного методом кейс-стади, но, с другой стороны, помогает выделить характерные закономерности, конструирующие типичные случаи и задающие повторяющиеся сценарии реинтеграции и ресоциализации.

В перечень критериев, не только формирующих сценарии, но и позволяющих их экстраполировать на другие социально-поддерживающие организации, можно включить режимы взаимоотношений между педагогами и воспитанниками - коммуникативные практики, особенности власти и подчинения во взаимоотношениях. Я выделяю четыре типа, которые на практике могут воспроизводиться в смешанных формах, то есть иметь признаки двух или более режимов.

Режим формального контроля и опеки. Данный режим описывает, как выстраиваются взаимоотношения, когда "взрослые" исполняют роль формального надзирателя, а воспитанники - неповинующегося подростка. Работники организации в своей деятельности в основном опираются на нормативные регулятивы либо прибегают к способам "жесткого" давления (оскорбительной стигматизации, физической силе), когда первые не срабатывают:

Инт.: Не нравится русский и литература, я так понимаю?

Инф.: Ну, когда в вас ножницы полетели, что бы вы сказали? (Максим, 14 лет, ученик школы VII вида)

Взаимоотношения между работниками и воспитанниками напряженные, крайне конфликтные. Педагоги не стремятся к доверительным взаимоотношениям с учениками, желают абстрагироваться от них. Подростки отличаются демонстративным и протестным поведением: 
И, конечно, они там и срывают уроки, и у нас конфликты. У нас очень часто милиция... в школе, потому что мы вынуждены прибегать... вот. У нас нет никаких рычагов воздействия, то есть мы их даже тряхануть не можем! Порой бывают такие случаи, что они и оскорбляют в лицо, и унижают, матерят, потому что в основном женский персонал работает. Очень сложно. Прибегаем к полиции, приезжают, увозят. (Женщина, 49 лет, завуч в школе VII вида)

Режим демократичного контроля и опеки характеризуется моделями взаимоотношений, в которых работа педагога с подростком хоть и основана на внутренних формальных положениях, но отличается доверительными отношениями и "мягкими" способами влияния. Подростку дозволяется право самоопределения своего досуга, активного или пассивного участия в жизни организации, однако взамен требуется исполнение определенных обязательств (посещение учебы, соблюдение правил поведения и т.д.). Воспитанники в целом уважительно относятся к работникам организации, но большинство педагогов не являются для них авторитетом:

Поэтому мы первое время разрешаем перейти из группы в группу, с профессии в профессию, из комнаты в комнату. Разрешаем. Давить нельзя. А зачем давить? Он, может, вот пришел, написал - слесарем, да, с месяц... эээ... там две недели отработал слесарем, он понимает, что не мое. Если будем давить, то он вообще уйдет-раз. Это его право, потому что у нас открытое училище. (Женщина, 51 год, завуч в специальном учебно-воспитательном учреждении - проф. училище)

В ситуации воспроизводства режима гиперопеки и контроля, напротив, "взрослые" стремятся проконтролировать практически все стороны жизни воспитанников, жестко регламентировать их деятельность. Однако при таком авторитарном давлении работники используют "мягкие" способы общения, исключая оскорбления, употребляя уменьшительно-ласкательную лексику, уговоры:

Простым языком. И бывают тихие прогульщики. Я их люблю немножко меньше, потому что с ними надо намного больше возни, чтобы их извлечь и заставить ходить в школу. Приятнее хулиганы, которые, зато, каждый день здесь. Вот бывают прогульщики, да, такие тихие сони просто, которых надо будить там, со всеми в семье разыскивать, бабушек-дедушек, мам, пап уговаривать ребенка все-таки разбудить и выпинать. Вот. Бывают такие товарищи. (Женщина, 29 лет, воспитатель в специальном учебновоспитательном учреждении открытого типа)

В модели наставничества и опеки коммуникация между "взрослыми" и подростками построена на доверительных взаимоотношениях, отличается большой степенью дозволения и минимальной дистанцией. Подросток боится нарушить формальные предписания и потерять доверие наставника. Педагог признается авторитетом и оказывает исключительное влияние на подростка:

Все время стараюсь брать пример с нашего главного тренера Алексея. Мне кажется, что это святая святых вообще, мне кажется, что такого нигде не встретишь вообще, 
мне кажется, что это один на миллион вообще. Он говорит такие вещи, он знает на все ответы всегда. И он... если его спросить о чем-то, всегда тебе объяснит, что да как, он тебе даст жизненный совет, он тебе поможет, если надо. Он мне за это время много чем помог. (Иван, 15 лет, некоммерческая организация, предоставляющая социальнокультурные услуги)

Кроме перечисленных режимов, которые так или иначе воспроизводятся во всех социально-поддерживающих организациях, можно выделить еще один типичный критерий, конструирующий сценарий,- отсутствие/наличие переезда к месту обучения. В организациях участники могут солидаризироваться на основании общих разделяемых ценностей и культурных идей, в этих процессах есть ключевые участники, а есть буферные или не включенные участники. Проживание подростка в общежитии или совместно разделяемый досуг с другими воспитанниками определяют его роль и позицию в коллективе организации. Например, в общежитии могут формироваться соседские взаимоотношения, предполагающие наличие иерархии, и не включенные в них воспитанники могут оказаться аутсайдерами в группе. Отрыв от прежнего социального окружения и переезд на место обучения предполагает погружение в новую среду в роли "туриста", что впоследствии разрывает контакты с прежней криминализированной средой.

Еще одним важным критерием является уклон деятельности организации, например, спортивный или творческий, профессиональная подготовка. Благодаря этому конструируется символическое пространство, в отдельных случаях - даже целые культуры, имеющие определенные фильтры для участников.

Таким образом, можно наблюдать определенные роли и декорации, в которых разворачиваются сценарии реинтеграции и ресоциализации "трудных" подростков в социально-поддерживающих организациях. Режимы взаимоотношений между педагогами и воспитанниками определяют роли и статусы, декорации оформляют сцену, выделяют специфичность среды, в которой происходит социальное действие.

\section{Что нельзя экстраполировать: частные критерии, задающие мультипликацию сценариев}

Сценарии реинтеграции и ресоциализации в каждой конкретной организации имеют специфический набор образующих критериев, и в этом заключается их уникальность. При общих декорациях и ролях воспроизводится неповторимый сюжет. Далее выделим эти частные критерии как набор признаков, подчеркивающих исключительность и индивидуальность каждого случая.

Во-первых, к ним следует отнести финансовые возможности и ресурсы социально-поддерживающей организации, определяющие внутренние особенности ее среды. Очевидно, что подростки предпочитают проводить больше времени там, где на высоком уровне материально-техническая и культурная база:

И, конечно, я думаю, что это от директора отчасти идет - и сама школа, само это здание. Старинное, чистенькое все такое, историчное. Тоже, наверное, как-то действует, потому что ребята, как только устраиваются в школу, они ходят как в музей там: снимают селфи 
на фоне гобелена там, на то-се, потом просят, нельзя ли привести там девушку, друзей - показать, в какой я школе учусь. (Женщина, 29 лет, воспитатель в специальном учебно-воспитательном учреждении открытого типа)

Немаловажно, какими методами и способами педагоги обучают и работают с подростками. Зачастую это может быть какой-либо особый метод, используемый работниками. К примеру, в случае некоммерческой организации, предоставляющей социально-культурные услуги с цирковым уклоном, особым методом воспитания, сочетающим в себе цирковую и социальную педагогику, могут считаться гастрольные туры и спонсируемые зарубежные поездки. К методу воспитания также можно отнести сам процесс реинтеграции в контексте наличия у конкретных педагогов или организации в целом связей и договоренностей с городскими секциями, клубами, молодежными пространствами, музеями, которые позволяли бы вовлекать молодых людей в их деятельность. Таким образом подросток обрастает новыми контактами, преодолевает фильтры учреждений и собственную стигму, возвращаясь в общество.

Например, в специальном учебно-воспитательном учреждении открытого типа (профессиональное училище), чтобы привлечь воспитанников к мероприятию, работники использовали педагогические хитрости в обход прямого давления:

Вот, поэтому сначала они пробегают. Мы одно время пытались всех заставить -было такое, впрочем, но потом стали делать так: должны на экскурсию-листочек повесим, ручку повесим. Кто хочет на экскурсию. Вот, а потом оказывается чаще всего, чем то, что "все едут на экскурсию!", да, и вот этот листочек. И оказалось: больше едут, когда вот на листочке он у нас сам записался. Вот, и поэтому точно так же и мероприятие. Вот будет мероприятие, вы придете? И начинается... Мероприятие начнется-их может быть десять человек... Потом начинается заглядывание: «Вот че это там? Ой, а че это там?». Так глядишь, и уже раз - и половина уже там. Поэтому мы стараемся что-то там более конкурсное, более такое... в общем, нравоучения засунуть в досуговую обертку. (Женщина, 51 год, завуч в специальном учебно-воспитательном учреждении - проф. училище)

Большую роль в конструировании уникальных ситуаций играет история учреждения и/или политика формирования кадрового состава. В нашем исследовании был пример, когда социально-поддерживающая организация государственного сектора оказалась создана путем реорганизации общеобразовательной школы. В связи с тем, что данная ситуация произошла в малом городе с ограниченным числом учебных заведений, большинство педагогов этой школы остались на прежних местах. Они прошли курсы повышения квалификации, но оказались морально не готовы к работе с "трудными" подростками:

Ну, это был период адаптации не только вот, да, детей. Педагоги тоже очень болезненно переходили, то есть первый год, я помню, был очень тяжелый. <...> Ну, и просто были все в шоке (смеется), что и родители такие не идут на контакты, и даже не пришли, не поинтересовались, куда их детей перевели. Как-то процесс адаптации шел трудно. (Женщина, 49 лет, завуч в школе VII вида) 
В некоторых примерах реинтеграция носит хаотичный характер, что объясняется развитостью городской среды. Такой феномен возникает, когда возможности города высоки, существуют инновационные и креативные площадки, популярные среди молодежи, но политика реинтеграции в социально-поддерживающей организации не имеет какой-либо четкой структуры. Воспитанникам организуют посещение самых популярных городских объектов практически каждый учебный день, не концентрируясь на одном конкретном направлении, в результате чего у подростков не формируется постоянных интересов и увлечений.

Таким образом, частные критерии придают уникальность процессу ресоциализации. Они скорее создают определенные барьеры, риски и возможности, чем напрямую трансформируют опыт группы подростков в рамках определенного сценария. Образующие критерии конструируют наиболее типичные модели, а частные критерии добавляют штрихи, задавая мультипликацию сценариев.

\section{Сценарии реинтеграции и ресоциализации: континуум вариаций}

Сценарии реинтеграции и ресоциализации представляют собой ситуативные модели поведения и последовательных действий "трудных" подростков с различной вариацией образующих и частных критериев в зависимости от институционального дизайна социально-поддерживающих организаций, определяющего те или иные практики и стратегии индивида.

Далее представлен континуум вариаций сценариев от оптимистических до пессимистических моделей с точки зрения успеха программ ресоциализации и реинтеграции в социально-поддерживающей организации. Континуум отображает мультипликацию сценариев реинтеграции и ресоциализации - множество моделей поведения подростка при тех или иных повторяющихся или уникальных условиях внешней и внутренней среды организации, то есть категоризациях, которые конструируют сам сценарий. На данный момент я выделила пять сценариев.

Сценарий слияния характеризуется абсолютной включенностью подростка в практики организации и личной мотивированностью на достижение конкретного результата. В коллективе присутствуют высокие фильтры к желающим включиться в организацию, которая имеет свой специфический уклон (театральная, спортивная деятельность). Претендент должен обладать определенными навыками, позволяющими ему беспрепятственно интегрироваться, получить признание и стать "своим" в коллективе. Распространены ситуации, связанные с конкурентной борьбой воспитанников за признание, победами и преодолением себя, постепенным поглощением и идентификацией с культурной направленностью организации. Вместе с этим подросток отдаляется от "другого" социального мира и людей, не обладающих определенным габитусом. Одним из образующих критериев является режим наставничества и опеки:

Для меня это... это [некоммерческая организация, предоставляющая социальнокультурные услуги с цирковым уклоном] уже как дом. И каждый день я сюда прихожу, для меня это уже полное счастье. Мне кажется, что я здесь уже... для меня за мои 15 лет - это как полжизни, я не знаю. Хоть я здесь мало и нахожусь [2,5 года], но мне кажется, что я здесь много провел времени. И я уже здесь все понял, что да как. Что 
делается, что да как... новое общество, компания. Ну, и все другое. (Ваня, 15 лет, воспитанник некоммерческой организации, предоставляющей социально-культурные услуги)

Сценарий беглеца - это обратная сторона сценария слияния. Он конструируется посредством сочетания режима наставничества и опеки, глубокого творческого уклона учреждения. Социально-поддерживающая организация, имеющая высокие фильтры входа в коллектив работников и воспитанников, блокирует его для тех подростков, которые не обладают требуемыми навыками. Высоки претензии к культуре тела, телесности, навыкам и умениям, силе воли и выносливости, если это спортивная или даже искусство-ориентированная организация со своим символическим пространством:

Ну говорили, что я дрищ, что я вообще никакой, что я говно последнее. Вот. Но сейчас я... себя чувствую очень комфортно. Спокойно так, хорошо. У меня есть друзья, слава тебе господи. И я рад, что они есть. Конечно, бывают проблемы, но все хорошо. <...> С Варей хорошо общаюсь. На самом деле мне очень жалко Варю, потому что ее постоянно обижают [в организации], прям даже сейчас. Ей часто говорят, что она толстая. (Дима, 15 лет, некоммерческая организация, предоставляющая социально-культурные услуги с цирковым уклоном).

Многие подростки не выдерживают давления фильтров, не справляются с задачей постоянного совершенствования навыков, бросают организацию. "Беглецом" воспитанник может стать на разных этапах входа. Подросток может покидать социально-поддерживающее учреждение совсем или на некоторое время, затем возвращаться, либо же становиться "аутсайдером" в группе, занимая низшие позиции в иерархии.

Сценарий выхода за рамки связан с ситуациями преодоления подростками различных ограничений и барьеров в новой для них социальной среде. Большинство молодых людей, принявших участие в исследовании, переехали на место обучения в ранее незнакомый для них город и проживают в общежитии. Поэтому внутри организации возникают отношения соседства, складываются свои традиции и иерархии. Взаимодействие со "взрослыми" строится на принципах демократичного контроля и опеки. Данный режим оказывается благоприятной почвой для развития различных сообществ по интересам, инициатив воспитанников, четкой лидерской структуры управления в коллективе сверстников. Организация имеет профессиональный или спортивный уклон, поэтому воспитанники (ре)интегрируются в производственные, спортивные сообщества в городе:

Я занимался пауэрлифтингом в прошлом году, в сороковухе [училище]. Дальше - сороковое, железнодорожное училище. Ездил на соревнования, но моей весовой категории не было. Но были краевые соревнования. Потом воркаутом занимался. Вот недавно был на соревнованиях. Но они были неофициальные. (Виктор, 17 лет, воспитанник специального учебно-воспитательного учреждения) 
Однако все это достигается через конкурентную борьбу за лидерские позиции и право влияния внутри организации, за победу в спортивных состязаниях, лучшее рабочее место в производственных кластерах города и т.д.

Сценарий подчинения режиму повествует об опыте группы подростков, которая испытывает сильное давление распорядка дня социально-поддерживающей организации. Режим взаимоотношений между работниками и воспитанниками строится на гиперопеке и повышенном контроле. Большинство обучающихся подростков проживают в городе, и внутри организации не формируются взаимоотношения соседства, тесных дружеских контактов. Все инициативы спускаются "сверху", повседневность подростков полностью регламентируется организацией. Повышенная забота и внимание со стороны "взрослых" способствуют сглаживанию любых конфликтов во взаимоотношениях, стимулируют воспитанников к рефлексии и сравнению с предшествующим опытом обучения:

Ну, это рай, да, как бы, тут подбирают специальных учителей для учеников, чтобы не было никакой жесткости. <... Там [в прошлой школе] всем учителям посрать. Главное, чтобы ты закончил - и просто пинками из этой школы. Вот, а здесь как бы наоборот. Здесь на каждого внимание, на каждого уделят свое внимание. (Игорь, 14 лет, ученик специального учебно-воспитательного учреждения)

Все воспитанники полностью подчиняются режиму дня в организации, соблюдают требования и нормативы:

Не то, что секция, просто вообще, как бы план, чтобы такого не было, что все по разным местам бегают или еще че-нибудь, а чтоб все вместе были, как бы общались между собой, то есть в шесть, вот, гулять выходим, допустим, во дворе. Либо футбол, либо еще че-нибудь ребята играют. (Василий, 16 лет, ученик учебно-воспитательного учреждения)

Внутри учреждения редко организуются какие-либо активности помимо предусмотренных образовательной программой или секцией. В учебном заведении подростки играют роль "подчиняющегося режиму", а за его пределами снова становятся завсегдатаем дворовых компаний:

Просто у нас щас опять завелась такая... человек, который все в компании сливает кому-то информацию. В итоге нам забили стрелу. В среду, в 7 часов - 200 на 200. Вот мы немножечко офигели. <...> Прийти за полчаса до всего этого и посмотретьпридет ли кто-нибудь или нет. Потому что реально все это так интересно. Вот, так что в среду мне надо как-то пораньше освободиться из школы. Вот, и все это посмотреть. (Аркадий, 15 лет, ученик специального учебно-воспитательного учреждения).

Сценарий изоляции связан с постоянными ситуациями эксклюзии, с которыми сталкиваются подростки. Это могут быть барьеры реинтеграции во внешней среде за пределами организации, с которыми имеют дело подростки, включаясь в городские сообщества и другие компании, например, ситуации стигматизации. 
Также постоянные баталии внутри самой организации: конфликты и стычки между сверстниками, с одной стороны, между воспитанниками и "взрослыми" - с другой. Данный сценарий конструируется под влиянием режима формального контроля и опеки в учреждении, отсутствия переезда молодых людей на место обучения. Внутри организации подростки сталкиваются с оскорбительной стигматизацией со стороны "взрослых", ограничением возможностей участия в каких-либо городских мероприятиях, угрозами:

Инф. Меня это не касается. Я редко появляюсь в школе. Неохота учиться. <...> Да нет, просто бывает - припугивают спецшколой.

Инт. Спецшколой - это какой спецшколой?

Инф. Спец... короче типа тюрьмы.

Инт. Ого. Почему так? Почему именно припугивают - за то, что не посещаешь?

Инф. Да. Но я сказала: отправляйте хоть куда. (Маша, 13 лет, ученица школы VII вида)

Подростки не включаются ни в какие инициативы, исходящие "сверху", и не предлагают своих. За пределами организации они оказываются исключены из городской жизни из-за статуса ученика коррекционной школы, вписываются в ряды "дворовых" объединений. Жизненные шансы воспитанников сильно ограничены, многие из них становятся участниками криминальных инцидентов и/или криминальных субкультур:

Мне вот исправительные работы и все. Ну щас он [друг] сюда приедет. <...> Он там пошел... с пацанами в магазин. Ограбил. Ну, и все, и потом ко мне пришли и сказали, что типа я его там заставлял, не заставлял. Хотя он на два года старше меня. (Виталий, 16 лет, школа VII вида)

Для более четкого понимания в таблице 1 систематизированы категоризации, конструирующие каждый выделенный сценарий.

Таблица 1. Континуум сценариев реинтеграции и ресоциализации "трудных" подростков

\begin{tabular}{|c|c|}
\hline Основные характеристики & Категоризации \\
\hline \multicolumn{2}{|c|}{ Сценарий слияния (происходит ресоциализация и реинтеграция) } \\
\hline $\begin{array}{l}\text { - Включенность подростка в практики } \\
\text { организации. } \\
\text { - Подросток идентифицирует себя с на- } \\
\text { правленностью деятельности (уклоном) } \\
\text { организации. } \\
\text { - Длительный вход подростка в сообщество, } \\
\text { высокие фильтры отбора кандидатов. } \\
\text { - Путь подростка в рамках данного сцена- } \\
\text { рия связан с постоянным преодолением } \\
\text { себя на различных этапах адаптации в ор- } \\
\text { ганизации до момента достижения полной } \\
\text { идентификации с ее символическим про- } \\
\text { странством и деятельностью. }\end{array}$ & $\begin{array}{l}\text { Образующие условия: } \\
\text { - Режим наставничества и опеки между взрос- } \\
\text { лыми и воспитанниками. } \\
\text { - Подросток проживает в городе без отрыва } \\
\text { от семьи или лиц, заменяющих ее. } \\
\text { - Ярко выраженный уклон организации: творче- } \\
\text { ская молодежная культура. } \\
\text { Частные условия: } \\
\text { - Особенность среды внутри организации: скон- } \\
\text { струированное символическое пространство. } \\
\text { - Уникальный метод воспитания. } \\
\text { - Кадровые особенности (например, старшие } \\
\text { воспитывают младших). }\end{array}$ \\
\hline
\end{tabular}




\begin{tabular}{|c|c|}
\hline Основные характеристики & Категоризации \\
\hline \multicolumn{2}{|c|}{ Сценарий выхода за рамки (происходит ресоциализация и реинтеграция) } \\
\hline $\begin{array}{l}\text { - Расширение контактов подростка. } \\
\text { - Преодоление стигмы, реинтеграция под- } \\
\text { ростка в производственные сообщества } \\
\text { и молодежные культуры. } \\
\text { - Сложная адаптация в организации: } \\
\text { внутри организации возникают взаимоотно- } \\
\text { шения соседства, формируются свои тради- } \\
\text { ции, иерархии; с взрослыми выстраиваются } \\
\text { нейтральные взаимоотношения. } \\
\text { — Подросток сталкивается со сложностями } \\
\text { реинтеграции во внешней среде после } \\
\text { того, как получает признание в коллективе } \\
\text { сверстников. }\end{array}$ & $\begin{array}{l}\text { Образующие условия: } \\
\text { - Искусственный отрыв подростка от привычной } \\
\text { социальной среды и переезд для продолжения } \\
\text { обучения. } \\
\text { - Режим демократического контроля. } \\
\text { - Производственный и спортивные уклоны } \\
\text { организации. } \\
\text { Частные условия: } \\
\text { - Производственная и спортивная инфраструк- } \\
\text { тура внутри организации (цеха, спортклубы). } \\
\text { - Особый метод воспитания: посредничество } \\
\text { учреждения (проработка договоренностей } \\
\text { с производственными организациями, спор- } \\
\text { тивными секциями). } \\
\text { - Кадровая политика: внимание к личным } \\
\text { качествам. }\end{array}$ \\
\hline
\end{tabular}

Сценарий подчинения режиму (слабая ресоциализация, хаотичная реинтеграция)

- Поглощение подростка режимом учреждения, формальное и неформальное включение в практики и повседневность организации.

- Подросток исполняет требуемые от него нормативы, не проявляя инициатив, поддерживает качество учебы и дисциплины на минимально требуемом организацией уровне.

- Воспитанник проходит быструю адаптацию в организации, контакт с работниками устанавливается раньше, чем со сверстниками.

- На выходе из учреждения после учебного дня подросток сбрасывает роль “подчиняющегося режиму" и включается в практики "дворовых" компаний.
Образующие условия:

- Отсутствие отрыва подростка от привычной ему среды, проживание в городе с семьей или лицами, ее заменяющими.

- Режим гиперопеки и контроля.

- Отсутствие уклона организации.

Частные условия:

- Особый стиль воспитания: гиперопека;

- Строгость режима организации, у воспитанников личное время ограничено.

Сценарий беглеца (нет ресоциализации и реинтеграции)

- Возникает множество ситуаций, связанных с фильтрами входа в сообщество сверстников на различных этапах развития сценария.

- Подросток учится определенным требуемым навыкам и культурным атрибутам в группе, не справляется и покидает организацию.

- Желание ухода/уход из организации может появиться/произойти в начале адаптации, в ситуации частичного слияния с организацией, а также на этапе близкого завершения обучения.

- После выхода происходит возвращение в практики "старых" компаний и/или изменение сферы деятельности.

- Подросток может возвращаться в организацию, проходить фильтры и испытания заново.
Образующие условия:

- Режим наставничества и опеки между взрослыми и воспитанниками.

- Подросток проживает в городе без отрыва от семьи или лиц, заменяющих ее.

- Ярко выраженный уклон организации или обособленная молодежная культура.

Частные условия:

- Особенность среды внутри организации: сконструированное символическое пространство.

- Высокие фильтры входа, не соответствие подростка предъявляемым качествам и критериям.

- Уникальный метод воспитания.

- Кадровые особенности (например, старшие воспитывают младших). 


\begin{tabular}{|c|c|}
\hline Основные характеристики & Категоризации \\
\hline \multicolumn{2}{|c|}{ Сценарий изоляции (нет ресоциализации и реинтеграции) } \\
\hline $\begin{array}{l}\text { - Подросток сталкивается с ситуациями } \\
\text { эксклюзии. } \\
\text { - Разрушение контактов как внутри органи- } \\
\text { зации, так и за ее пределами. } \\
\text { - Взаимоотношения со взрослыми } \\
\text { и сверстниками основаны на постоянных } \\
\text { конфликтах. } \\
\text { - Подросток может включаться в крими- } \\
\text { нальные субкультуры, могут происходить } \\
\text { криминальные инциденты в организации. } \\
\text { Жизненные возможности подростка } \\
\text { в данном сценарии сильно ограничены } \\
\text { из-за стигматизации и идентификации } \\
\text { со стигмой. }\end{array}$ & $\begin{array}{l}\text { Образующие условия: } \\
\text { - Режим формального контроля и опеки. } \\
\text { - Подросток проживает в городе без отрыва } \\
\text { от семьи или лиц, заменяющих ее. } \\
\text { - Городская среда с невысокими жизненными } \\
\text { шансами для молодежи (отток молодежи из го- } \\
\text { рода, ограниченное количество возможностей } \\
\text { для досуга и образования молодежи). } \\
\text { - Отсутствие у организации уклона деятельности. } \\
\text { Частные условия: } \\
\text { - Ограниченные ресурсы организации и ее } \\
\text { возможности из-за плохой репутации среди } \\
\text { городской молодежи. } \\
\text { - Особый метод воспитания: давление, стигма- } \\
\text { тизация воспитанников. } \\
\text { - Особенности кадровой политики: нет спе- } \\
\text { циалистов с опытом работы в специальных } \\
\text { учреждениях. }\end{array}$ \\
\hline
\end{tabular}

\section{Выводы: сильные и слабые стороны сценарного подхода}

Сценарный подход предлагает возможность прогнозирования и моделирования программ ресоциализации подростков в социально-поддерживающей организации. Это означает, что сценарий можно "переписывать" в соответствии с целями учреждения, для совершенствования программ и прогнозирования их исходов.

Найти ответ на вопрос, как переписать сценарий реинтеграции и ресоциализации "трудных" подростков, можно путем образовательных и социальных экспериментов. К примеру, актуально внедрение в социально-поддерживающую организацию аналитических методов исследования, направленных на изучение вызовов среды и работы с ними - своеобразного риск-менеджмента. В подавляющем числе случаев подобная работа проводится исключительно интуитивно, во многом опирается на социальный капитал и связи самих работников. Например:

Мы приглашали к ним, очень часто приглашаем к себе лицей, там есть хороший ансамбль "Огонек". И мы очень часто приглашаем на концерты на разные свои - там девчонки танцуют. Мальчишки, конечно, глаза загораются сразу, сразу начищают до блеска свои ботинки. Одеваются сразу красиво, прилично. Вот. И им нравится это, потом у нас есть школа - мы оттуда приглашали певческий коллектив. Вот. Потом c 20-го [училища] к нам приезжала “Ягодка", мы вот пытаемся сотрудничать, где я работала. Я работала и там, и там, и там, и оттуда всех приглашаем к себе, чтобы было интересно, чтобы им было не скучно, чтобы они не замыкались только вот... они здесь - и все. (Женщина, 55 лет, завуч по хозяйственной части в специальном учебновоспитательном учреждении - проф. училище)

В конкретном примере существовали барьеры, связанные с ограниченным финансированием, стигматизацией воспитанников и самого учреждения извне, 
поэтому педагоги были вынуждены использовать собственные "проверенные" ресурсы, привлекать на работу тех, кто имеет обширный опыт социальной и педагогической работы и, соответственно, связи. Контакты хоть и расширялись через "новых" работников, но замыкались на конкретном перечне дружественных организаций, городских сообществ или творческих коллективов. Поэтому необходима создание инструментария для работы с вызовами внешней среды, к примеру, проект программы развития волонтерства совместно с отделением "Красного Креста" или другими специализированными организациями.

Рассмотрим следующий случай. Социально-поддерживающая организация находится в мегаполисе, что подразумевает широчайший спектр возможностей, но накладывает риск городской сегрегации: подростки могут оказаться дезориентированы в городе. Кроме того, проводимые исследования выявляют, что в организации складывается режим гиперопеки и контроля в отношениях между работниками и подопечными, что с большей вероятностью приведет к формированию сценария подчинения режиму. Так как политика реинтеграции хаотична и вписана в регламент дня организации, подростки не включаются практически ни в какие городские сообщества, оседая и укрепляясь в позициях в своем конкретном районе, конфликтуя с "другими". Для того, чтобы "переписать" данный сценарий, необходимо продумать политику реинтеграции. Например, начать с вводных экскурсий в конкретные районы города или социально-культурные объекты, а затем проводить углубленные экскурсии или выездные занятия с разными уклонами и тематиками в тех же местах. Также в данном случае крайне необходимо создание структуры самоуправления внутри коллектива воспитанников, что способствовало бы проявлению инициатив.

Разумеется, все сценарии имеют как сильные, так и слабые стороны, можно только условно выделять наиболее "оптимистичные" и "пессимистичные" с точки зрения самоощущения информантов. Например, сценарий слияния, при весьма оптимистичных и восторженных отзывах интервьюируемых, предполагает определенную дезинтеграцию воспитанников в обществе, выражающуюся в сокращении социальных контактов вне организации. Мир подростка складывается из "своих" и "чужих", причем "своими" признаются только те, кто разделяет нормы внутренней культуры организации, "чужие» - все остальные - горожане, одноклассники и даже родители:

Ну, они [одноклассники, учителя и пр.] такие, знаете, "типичные чуваки". Знаете... есть стереотип в [организации], что они просто клоуны. И когда я уезжаю на всякие гастроли и мне сказали, что моя класснуха, она очень ругалась, потом сказала, что у меня не жизнь, а малина. И меня до сих пор с этого вынашивает. Ну, мне смешно... просто смешно. <...> Просто я понимаю, что людей засовывают в квадрат и им говорят делать так, и они делают так. У них нет собственного мнения, и это отстой. <...> Иногда я чувствую, что меня защемляют, иногда я чувствую, что могу творить. Ну, мы же иногда делаем сами номера помимо. Просто хотим и делаем. (Дмитрий, 15 лет, некоммерческая организация, предоставляющая социально-культурные услуги)

Сценарный подход к изучению реинтеграции и ресоциализации накладывает и ограничения в исследованиях. Не всегда возможно проследить гендерные 
вариации сценариев, поскольку число юношей и исключительно "мужских" социально-поддерживающих организаций превалирует. Кроме того, метод требует тщательнейшей детализации места локализации, глубокого анализа дизайна организации, широкого спектра методов и теорий для объяснения выдающихся случаев, нуждается в дополнительной фокусировке. Понять и описать сценарий можно, лишь исключительно глубоко проникнув в повседневность социальноподдерживающей организации, но абстрагируясь при этом от практик нормативного контроля и коррекции воспитанников, навязываемых работниками с момента появления исследователя в данном учебном заведении. Подход требует дополнительных исследований, детализации, в том числе с проведением экспериментов.

\section{Список литературы}

Беккер Г. С. Аутсайдеры: исследования по социологии девиантности. М.: Элементарные формы, 2018.

Becker H.S. (2018) Outsiders: Studies in the Sociology of Deviance. Moscow: Elementary Forms Press. (In Russ.)

Бредникова О.Е. (Не)возвращение: могут ли мигранты стать бывшими? // Этнографическое обозрение. 2017. № 3. С. 32-47.

Brednikova, O. E. (2017) The (Non-)Return: Can Migrants Become Former Migrants? Etnograficheskoe obozrenie. No. 3. P. 32-47. (In Russ.)

Головизнина М.В.Преступность несовершеннолетних, ювенальная юстиция и восстановительное правосудие в Италии // Вопросы ювенальной юстиции. 2007. № 2. C. $44-47$.

Goloviznina M. V. (2007) Juvenile Delinquency, Juvenile Justice and Restorative Justice in Italy. Questions of Juvenile Justice. No. 2. P. 44-47. (In Russ.)

Лисовская И. В. «Путевка в жизнь" для "трудных" подростков? Возможные сценарии (ре)интеграции в специальных учреждениях // Журнал исследований социальной политики. 2019. № 3. С. 423-438.

Lisovskaya I. V. (2019) A 'Start in Life' for Troublesome Kids? Possible Scenarios of Reintegration in The Context of Special Institutions. The Journal of Social Policy Studies. No. 3. P. 423-438. (In Russ.)

Клепикова А.А., Утехин И.В. Ребенок с "отклонениями развития": опыт анализа фреймов // Антропологический форум. 2010. № 12. С. 1-68.

Klepikova A. A., Utekhin I. V. (2010) A Child with “Developmental Disabilities": The Experience of Frame Analysis. Anthropological Forum. No. 12. P. 1-68. (In Russ.)

Лернер Ю., Рапопорт Т., Ломски-Федер Э. Русскоязычные студенты в израильском университете: как работает "этнокультурный сценарий" советских евреев в эмиграции // Диаспоры. 2009. № 2. С. 62-90.

Lerner J., Rapoport T., Lomsky-Feder E. (2009) Russian-Speaking Immigrant Students in Israeli Universities: The "Ethnocultural Script” in Action. Diasporas. No. 2. P. 62-90. (In Russ.) 
Маколи М. Дети в тюрьме / пер. с англ. Е. Мишкинюк. М.: ОГИ, 2008. Makoli M. (2008) Children in Prison. Transl. from English E. Mishkinuk. Moscow: OGI. (In Russ.)

Омельченко Е.Л. Молодежные культуры и субкультуры. М.: Институт социологии PAH, 2000.

Omelchenko E. L. (2000) Youth Cultures and Subcultures. Moscow: Institute of Sociology RAS. (In Russ.)

Омельченко Е.Л. Молодежь: открытый вопрос. Ульяновск: Симбирская книга. 2004.

Omelchenko E. L. (2004) Youth: An Open Issue. Ulyanovsk: Simbirskaya kniga. (In Russ.)

Омельченко Е. Л. Начало молодежной эры или смерть молодежной культуры? "Молодость" В публичном пространстве современности // Журнал исследований социальной политики. 2006. № 2. С. 151-182. (In Russ.)

Omelchenko E. L. (2006) The Beginning of the Youth Era or the Death of Youth Culture? "Youth" in the Public Space of our Time. Journal of Social Policy Study. No. 2. P. 151182. (In Russ.)

Павлов Б. С. Над опасным "социальным придоньем" (о девиантной субкультуре подростков) // Социологические исследования. № 2. 2013. С. 69-79.

Pavlov B.S. (2013) Over the Dangerous “Social Bottom" (About the Deviant Subculture of Adolescents). Sociological Studies. No. 2. P. 69-79. (In Russ.)

Сидоров Н. Р., Бондаренко И.Н. Исследование социально-психологических особенностей воспитанников специальных школ открытого типа //Прикладная юридическая психология. 2012. № 2. С. 63-73.

Sidorov N. R., Bondarenko I. N. (2012) Research of Socio-Psychological Features of Pupils of Special Schools of Open Type. Applied Legal Psychology. No. 2. P. 63-73. (In Russ.)

Ярская В.Н., Ловцова Н.И. Молодежная политика: разные и пока не равные // Журнал исследований социальной политики. 2010. Т. 8. № 2. С. 151-164.

Yarskaya V. N., Lovcova N. I. (2010) Youth Policy: Different and Not Equal Yet. The Journal of Social Policy Studies. Vol. 8. No. 2. P. 151-164. (In Russ.)

Arowolo O. O. (2000) Return Migration and the Problem of Reintegration. International Migration. Vol. 38. No. 5. P. 59-82. https://doi.org/10.1111/1468-2435.00128.

Burnett R. (2009) Post-Corrections Reintegration: Prisoner Resettlement and Desistance From Crime. In: Adler J., Gray J. Forensic Psychology: Concepts, Debates and Practice. Cullompton: Willan.

Burnett R., Maruna S. (2006) The Kindness of Prisoners: Strengthsbased Resettlement in Theory and in Action. Criminology and Criminal Justice. Vol. 6. No. 1. P. 83-106. https://doi.org/10.1177/1748895806060668.

Giddens A. (1999) Risk and Responsibility. The Modern Law Review. Vol. 62. No. 1. P. $1-10$. 
Griffin C. (1993) Representation of Youth. The Study of Youth and Adolescence in Britain and America. Cambridge: Polity Press.

Humphreys M., Weinstein J. M. (2007) Demobilization and Reintegration. Journal of Conflict Resolution. Vol. 51. No. 4. P. 531-567. https://doi.org/10.1177/ 0022002707302790.

Muravyeva M. G. (2017) Russia. In: Schreck C. J. (ed.) The Encyclopedia of Juvenile Delinquency and Justice. Hoboken: Wiley. https://doi.org/10.1002/9781118524275. ejdj0194.

Ortner S. B. (1973) On Key Symbols. American Anthropologist. No. 5. P. 1338-1346.

Surette R. (2016) Measuring Copycat Crime. Crime, Media, Culture. Vol. 12. No. 1. P. 37-64. https://doi.org/10.1177/1741659015601172.

Swadener B. B., Lubeck S. (1995) The Social Construction of Children and Families "at Risk": An Introduction. In: Swadener B.B., Lubeck S. Children and Families "at Promise": Deconstructing the Discourse of Risk. Albany: State University of New York Press. P. $1-16$.

Tait G. (1995) Shaping the 'at-Risk Youth': Risk, Governmentality and the Finn Report. Discourse: Studies in the Cultural Politics of Education. Vol. 16. No. 1. P. 123-134. https://doi.org/10.1080/0159630950160108.

Ward T., Maruna S. (2007) Rehabilitation: Beyond the Risk Paradigm. London, New York: Routledge. 